\title{
Integrated Strategy for Management of Stem and Root Rot Disease of Sesame (Sesamum indicum L.) caused by Macrophomina phaseolina (Tassi) Goid in Odisha
}

\author{
B. K. Pani ${ }^{1 *}$, B. C. Dhir ${ }^{1}$, D. Panigrahi ${ }^{2}$ and D. R. Mishra ${ }^{1}$ \\ ${ }^{1}$ All India Coordinated Research Project on Sesame, Regional Research and Technology \\ Transfer Station, Mahisapat, Dhenkanal-759013, Odisha, India \\ ${ }^{2}$ Regional Research and Technology Transfer Station, Mahisapat, Dhenkanal-759013, \\ Odisha, India \\ *Corresponding author
}

\section{A B S T R A C T}

\section{Keywords}

Stem and root rot disease, Sesame, Macrophomina phaseolina

Article Info

Accepted:

17 June 2020

Available Online:

10 July 2020
An experiment was conducted to manage the stem and root rot disease of sesame incited by Macrophomina phaseiolina by a combination of new generation fungicides and biocontrol agents. Seven chemicals and a bio-agent, Pseudomonas fluorescens were tested separately in combinations with seed and soil treatments of Trichoderma viride vis-a-vis untreated control. Seed treatment with Trichoderma viride @ $10 \mathrm{~g} / \mathrm{kg}$ +furrow application of T. viride $(2.5 \mathrm{~kg}$ enriched in $250 \mathrm{~kg}$ FYM /ha combined with foliar application of azoxystrobin @ 1ml/l at 45 DAS and 60 DAS was found to be significantly effective in sustaining minimum disease incidence $(5.25 \%)$, maximum yield $(431.55 \mathrm{~kg} / \mathrm{ha}, 45.05 \%$ increase over control) and highest B:C ratio (1.54). It was followed by seed treatment and furrow application of Trichoderma combined with chemical sprays of carbendazim + mancozeb @ 2.5g/l (6.77\% disease incidence, $417.85 \mathrm{~kg} / \mathrm{ha}$ of yield, $40.45 \%$ increase in yield over control, B:C ratio of 1.40). All treatments significantly minimized infection and sustained higher seed yield compared to untreated control. Highest incidence $(16.21 \%)$ and minimum yield $(297.50 \mathrm{~kg} / \mathrm{ha})$ were recorded in the untreated crop. Spraying with chemical fungicides was found more effective vis-a-vis bio-control agent, Pseudomonas fluorescens, in managing the disease.

\section{Introduction}

Known as the 'Queen of oilseeds', sesame (Sesamum indicum L.) is one of the major oilseed crops of India. Among oilseeds, it ranks first in oil content with $6335 \mathrm{kcal} / \mathrm{kg}$ of dietary energy in seeds (Kumar and Goel, 1994). The seed is rich in protein $(20 \%)$ and 
edible oil $(50 \%)$ and contains $47 \%$ oleic acid and 39\% linolenic acid (Shyu and Hwang, 2002). Moreover, certain biologically active and health promoting phyto-chemicals such as sesamin, sesamolin, tocopherols, PUFA, phytosterols, phytates and other phenolics were also present (Pathak et al., 2014).

Sesame seeds contain magnesium which has anti-cancer properties. India contributes the highest sesame acreage of above 17.73 lakh hectare with an estimated production 8 lakh tones and productivity of $445 \mathrm{~kg} / \mathrm{h}$ ectare (Gupta et al., 2019).

In Odisha, sesame is cultivated in an area of 203.19 thousand hectares with a production of 79.49 thousand tonnes (Anonymous, 2016). There are many biotic and abiotic stresses which are limiting sesame production and productivity. Among various biotic stresses, stem and root rot of sesame caused by Macrophomina phaseolina is reported as the most predominant disease in Odisha (Anonymous, 2018-2019). In India, the disease is prevalent in almost all sesame growing tracts.

The symptom of the disease starts with the yellowing of lower leaves, followed by drooping and defoliation. The stem portion near the ground level shows dark brown lesions and bark at the collar region shows shredding. The sudden death of plants is often seen in patches. In the older plants, the stem near the soil level shows large number of black pycnidia.

The stem portion can be easily pulled out leaving the rotten root portion in the soil. In case of severe infection, pods open prematurely, become shrivelled and black in colour.

Minute pycnidia are also seen on the infected capsules and seeds. The rotten root as well as stem tissues contains a large number of minute black sclerotia which may also be present on infected pods and seeds.

Macrophomina infects a wide host range of nearly 500 species occurring in more than 100 families around the world (Reznikov et al., 2016). Seed-borne nature of the pathogen and its ability to survive on left over crop residues make it difficult to manage the disease by any single approach (Choudhury et al., 2014). Therefore, an integrated approach was undertaken to manage stem and root rot disease of sesame in Odisha which included seed treatment with bio-agents and/or foliar application of different chemicals and a bioagent.

\section{Materials and Methods}

A field experiment was conducted at All India Co-ordinated Research Project on Sesame, Mahisapat, Dhenkanal during two consecutive kharif seasons of 2018 and 2019 involving a susceptible variety VRI-1 with eight treatments. Seeds treated with Trichoderma viride @ $10 \mathrm{~g} / \mathrm{kg}+$ furrow application of $T$. viride $(2.5 \mathrm{~kg}$ enriched in $250 \mathrm{~kg} \mathrm{FYM} / \mathrm{ha}$ were common in all treatments except the untreated control. Foliar spray with biocontrol agent Pseudomonas fluorescens @ 5g/1 was made at capsule initiation stage (45 DAS) and second spray was made after 15 days.

The chemical treatments include new generation fungicides like trifloxystrobin (25 $\%)+$ tebuconazole (50\%) WG @ 0.5 g/l, azoxystrobin (23 \% $\quad \mathrm{SC}) \quad @ \quad 1 \mathrm{ml} / 1$, pyraclostrobin $(5 \%)+$ metiram $(55 \%) \mathrm{WG}$ @ $3 \mathrm{~g} / \mathrm{l}$, cymoxanil $(8 \%)+$ mancozeb $(64 \%)$ WP @ 2 g/l, captan $(70 \%)+$ hexaconazole (50\%) WP @ 2g/l, carbendazim $(12 \%)+$ mancozeb (64\%) WP@ 2.5g/l which were used as foliar spray at capsule initiation (45 DAS) and second spray was made after 15days (60 DAS).

The experiment was carried out in 
randomized block design and three replications were maintained for each treatment. A roving survey was carried out in kharif, 2019 at different places of Dhenkanal district of Odisha to record the major diseases affecting the crop.

\section{Results and Discussion}

Survey conducted during kharif 2019 in five centres of All India Co-ordinated Research Project on Sesame across the country including AICRP on Sesame, Mahisapat, Dhenkanal, Odisha revealed that stem and root rot of sesame incited by Macrophomina phaseiolina was the major disease of sesame and the incidence ranged from 4.6 to 32.7 per cent (Table 1).

A perusal of pooled data (Table 2) revealed that all treatments significantly reduced stem and root rot infection and sustained higher seed yield in comparison to untreated control. Seed treatment with Trichoderma viride @ $10 \mathrm{~g} / \mathrm{kg}+$ furrow application of $T$. viride (2.5 $\mathrm{kg}$ enriched in $250 \mathrm{~kg} \mathrm{FYM} / \mathrm{ha}$ ) combined with foliar spray of azoxystrobin @ 1ml/1 at capsule initiation (45 DAS) and second spray after 15days (60 DAS) was found to be significantly effective in sustaining minimum disease incidence $(5.25 \%)$ and maximum seed yield $(431.55 \mathrm{~kg} / \mathrm{ha})$. It sustained 45.05 per cent higher yield compared to control and recorded the highest $\mathrm{B}: \mathrm{C}$ ration of 1.54 .

The next effective treatment included seed treatment and furrow application with Trichoderma combined with chemical sprays of carbendazim + mancozeb @ 2.5g/l (6.77\% disease incidence with a corresponding seed yield of $417.85 \mathrm{~kg} / \mathrm{ha}$ ). The effectiveness of Trichoderma sp. as an antagonist to $M$. phaseolina has earlier been reported (Wuike et al., 1995).
Sankar and Jeyrajan (1996) reported that $T$. harzianum significantly reduced root rot incidence, increased root and shoot length as well as yield and oil content. Highest incidence of Macrophomina phaseolina $(16.21 \%)$ and minimum yield $(297.50 \mathrm{~kg} / \mathrm{ha})$ were recorded in the untreated crop. It was further observed that spraying with chemical fungicides was more effective vis-a-vis biocontrol agent, Pseudomonas fluorescens, in reducing the infection and increasing the yield which corroborates earlier findings (Adhikary et al., 2019)

The use of bio-agents for plant disease management as a single approach is not much effective due to its inability to maintain a critical population density for sustained biological activity.

On the other hand, the chemical fungicides are preferred for effective disease management due to their easy adaptability and immediate curative action.

In the present investigation, the combination of $T$. viride (both as seed and soil treatment) coupled with a foliar application of azoxystrobin could effectively reduce Macrophomina infection and induce higher seed yield.

It is inferred from the study that an integrated approach involving seed treatment with biocontrol agent, Trichoderma viride @ 10g/kg + furrow application of $T$. viride $(2.5 \mathrm{~kg}$ enriched in $250 \mathrm{~kg} \mathrm{FYM} / \mathrm{ha}$ ) and subsequent foliar application of azoxystrobin @ $1 \mathrm{ml} / \mathrm{l}$ at capsule initiation and second spray at 15 days could be successfully adopted during sesame cultivation in Odisha for minimizing Macrophomina infection and maximizing yield. 
Table.1 Survey of sesame diseases in different AICRPs on Sesame conducted during Kharif 2019

\begin{tabular}{|c|c|c|c|c|c|c|c|c|}
\hline $\begin{array}{l}\text { Name of AICRP on } \\
\text { Sesame centre }\end{array}$ & $\begin{array}{c}\text { Macrophomina } \\
\text { stem and } \\
\text { root rot }(\%)\end{array}$ & $\begin{array}{c}\text { Phyllody } \\
(\%)\end{array}$ & $\begin{array}{l}\text { Leaf } \\
\text { curl } \\
(\%)\end{array}$ & $\begin{array}{c}\text { Cercospora } \\
\text { leaf spot } \\
(0-5 \text { grade })\end{array}$ & $\begin{array}{c}\text { Alternaria } \\
\text { leaf spot } \\
(0-5 \\
\text { grade })\end{array}$ & $\begin{array}{c}\text { Phytophthora } \\
\text { blight } \\
(0-5 \\
\text { grade) }\end{array}$ & $\begin{array}{c}\text { Bacterial leaf blight } \\
\text { (0-5 grade) }\end{array}$ & $\begin{array}{c}\text { Powdery } \\
\text { mildew } \\
(0-5 \\
\text { grade })\end{array}$ \\
\hline $\begin{array}{l}\text { Vridhachalam, } \\
\text { TNAU, Tamilnadu }\end{array}$ & $9.5-23.6$ & $3.8-14.6$ & - & - & $1-3$ & - & - & $1-3$ \\
\hline $\begin{array}{l}\text { RAU, } \\
\text { Mandor, Rajasthan }\end{array}$ & $25.2-32.7$ & $18.4-30.2$ & $3.0-5.2$ & $1-2$ & $0-1$ & - & $1-2$ & $0-1$ \\
\hline $\begin{array}{l}\text { UAS, Dharwad, } \\
\text { Karnatak }\end{array}$ & - & $5-10$ & - & $2-3$ & - & $2-3$ & - & - \\
\hline
\end{tabular}

(Source: Annual Report of AICRP on Sesame, 2019-20) 
Table.2 Management of stem and root of sesame caused by Macrophomina phaseolina

\begin{tabular}{|c|c|c|c|c|c|c|c|c|}
\hline \multirow[t]{2}{*}{ Treatments } & \multicolumn{3}{|c|}{ MSR incidence (\%) } & \multicolumn{4}{|c|}{ Seed yield $(\mathrm{Kg} / \mathrm{ha})$} & \multirow{2}{*}{$\begin{array}{l}\text { B:C } \\
\text { ratio }\end{array}$} \\
\hline & 2018 & 2019 & $\begin{array}{l}\text { Pool } \\
\text { Mean }\end{array}$ & 2018 & 2019 & $\begin{array}{l}\text { Pool } \\
\text { Mean }\end{array}$ & $\begin{array}{c}\text { Per cent } \\
\text { increase } \\
\text { over } \\
\text { control }\end{array}$ & \\
\hline $\begin{array}{l}\text { T1: Seed treatment with Trichoderma viride @ } \\
10 \mathrm{~g} / \mathrm{kg}(\mathrm{ST})+\text { furrow application of T. viride }(2.5 \\
\mathrm{kg} / \mathrm{ha} \text { enriched in } 100 \mathrm{~kg} \text { of FYM) @ } 250 \mathrm{~kg} / \mathrm{ha} \\
\text { (FA) + spraying of Pseudomonas fluorescens @ } \\
5 \mathrm{~g} / \mathrm{l} \text { at } 45 \text { DAS and } 60 \text { DAS }\end{array}$ & $\begin{array}{l}12.80 \\
(20.92)\end{array}$ & $\begin{array}{c}14.82 \\
(22.60)\end{array}$ & $\begin{array}{c}13.81 \\
(29.77)\end{array}$ & 350.00 & 361.60 & 355.80 & 19.59 & 1.26 \\
\hline $\begin{array}{l}\text { T2: ST +FA + }+ \text { spraying trifloxystrobin }+ \\
\text { tebuconazole @ } 0.5 \text { g/l at } 45 \text { DAS and } 60 \text { DAS }\end{array}$ & $\begin{array}{c}9.50 \\
(19.93)\end{array}$ & $\begin{array}{c}10.16 \\
(18.52)\end{array}$ & $\begin{array}{c}9.83 \\
(18.24)\end{array}$ & 399.60 & 381.66 & 390.63 & 31.30 & 1.33 \\
\hline $\begin{array}{l}\text { T3: ST +FA + spraying azoxystrobin @ } 1 \mathrm{ml} / \mathrm{l} \text { at } \\
45 \text { DAS and } 60 \text { DAS }\end{array}$ & $\begin{array}{c}4.70 \\
(12.57)\end{array}$ & $\begin{array}{c}5.80 \\
(13.93)\end{array}$ & $\begin{array}{c}5.25 \\
(13.24)\end{array}$ & 428.10 & 435.00 & 431.55 & 45.05 & 1.54 \\
\hline $\begin{array}{l}\text { T4: ST +FA + spraying pyraclostrobin + } \\
\text { metiram @ 3g/l at } 45 \text { DAS and } 60 \text { DAS }\end{array}$ & $\begin{array}{c}6.60 \\
(14.88)\end{array}$ & $\begin{array}{c}7.74 \\
(16.13)\end{array}$ & $\begin{array}{c}7.17 \\
15.52\end{array}$ & 405.00 & 405.00 & 405.00 & 36.13 & 1.20 \\
\hline $\begin{array}{l}\text { T5: ST +FA + spraying cymoxanil + mancozeb } \\
\text { @ } 2 \text { g/l at } 45 \text { DAS and } 60 \text { DAS }\end{array}$ & $\begin{array}{c}7.50 \\
(15.89)\end{array}$ & $\begin{array}{c}8.12 \\
(16.50)\end{array}$ & $\begin{array}{c}7.81 \\
(16.21)\end{array}$ & 401.30 & 403.33 & 402.31 & 35.23 & 1.11 \\
\hline $\begin{array}{l}\text { T6: ST +FA + spraying of captan }+ \text { hexaconazole } \\
\text { @ } 2 \text { g/l at } 45 \text { DAS and } 60 \text { DAS }\end{array}$ & $\begin{array}{c}7.20 \\
(15.56)\end{array}$ & $\begin{array}{c}7.93 \\
(16.35)\end{array}$ & $\begin{array}{c}7.56 \\
(15.96)\end{array}$ & 405.00 & 410.00 & 407.50 & 36.97 & 1.15 \\
\hline $\begin{array}{l}\text { T7: ST +FA + spraying carbendazim + } \\
\text { mancozeb } @ 2.5 \text { g/l at } 45 \text { DAS and } 60 \text { DAS }\end{array}$ & $\begin{array}{c}6.40 \\
(14.64)\end{array}$ & $\begin{array}{c}7.14 \\
(15.49)\end{array}$ & $\begin{array}{c}6.77 \\
(15.07)\end{array}$ & 415.70 & 420.00 & 417.85 & 40.45 & 1.40 \\
\hline T8: Water spray (Untreated check) & $\begin{array}{c}14.60 \\
(22.41)\end{array}$ & $\begin{array}{c}17.82 \\
(24.97)\end{array}$ & $\begin{array}{c}16.21 \\
(23.73)\end{array}$ & 290.00 & 305.00 & 297.50 & - & 1.13 \\
\hline SE(m) & 0.62 & 0.59 & 0.50 & 10.97 & 6.05 & 5.31 & & \\
\hline $\mathrm{CD}(0.05)$ & 1.89 & 1.78 & 1.52 & 33.28 & 18.34 & 16.11 & & \\
\hline
\end{tabular}




\section{References}

Anonymous.2016. Odisha Agriculture Statistics, Department of Agriculture and Farmers Empowerment, Govt. of Odisha.

Anonymous. 2018-2019.Survey of Sesame diseases. Annual Report of Sesame and Niger, All India Co-ordinated Research Project, Sesame and Niger (2019-20)

Choudhury, C.S., Anjana Arun and Prasad, S.M. 2014. Management of stem and root rot of sesame. International Journal of Agricultural Science 1092): 755-760

Gupta, K.N., Naik, K.R. and Rajani Bisen. 2019. Status of sesame diseases and their integrated management using indigenous practice. International Journal of Chemical Studies 2018; 6(2): 1945-1952

Kumar, S. and Goel, P.D. 1994. A great ancient oilseed sesamum. Farmers and Parliament. 12: 6-7.

Nayan Kishor Adhikary, Md. Riton Chowdhury, Tamina Begum and Rambilash Mallick. 2019. Integrated Management of Stem and Root Rot of
Sesame (Sesamum indicum L.) caused by Macrophomina phaseolina (Tassi) Goid. International Journal of Current Microbiology and Applied Sciences 8(04): 804-808.

Pathak N, Rai AK, Ratna Kumari KV, Bhat.2014. Value addition in sesame: A perspective on bioactive components for enhancing utility and profitability, Pharmacognosy Reviews 8(16):147155.

Sankar,P. And Jeyrajan, R.C.1996.Biological control of sesame root rot by seed treatment with Trichoderma sp. and Bacillus subtilis. Indian Journal of Mycology and Plant Pathology 26(2)217-220

Shyu,Y. S. and Hwang, L. S. 2002. Antioxidative activity of crude extract of lignin glycosides from unroasted Burma black sesame meal. International Food Research 35: 357365

Wuike,R.V., Nanoti, A.A., Bhoyate,S.G. and Kitkoru, R.D. 1995. Biocontrol of $\mathrm{root} / \mathrm{stem}$ rot of sesame with antagonists, Trichoderma viride. Journal of Soil and Crops 592): 145147.

\section{How to cite this article:}

Pani, B. K., B. C. Dhir, D. Panigrahi and Mishra, D. R. 2020. Integrated Strategy for Management of Stem and Root Rot Disease of Sesame (Sesamum indicum L.) caused by Macrophomina phaseolina (Tassi) Goid in Odisha. Int.J.Curr.Microbiol.App.Sci. 9(07): 19501955. doi: https://doi.org/10.20546/ijcmas.2020.907.222 